\title{
Investigation of the Relationship between Parental Attitudes and Children's Receptive and Expressive Language Skills
}

\author{
Şenay Özen Altınkaynak \\ Department of Early Childhood Education, Faculty of Education, Kafkas University, Turkey
}

Copyright $\mathrm{C} 2019$ by authors, all rights reserved. Authors agree that this article remains permanently open access under the terms of the Creative Commons Attribution License 4.0 International License

\begin{abstract}
The purpose of the current study is to determine the relationship between parental attitudes and children's receptive and expressive language skills. In the current study investigating the relationship between parental attitudes and children's expressive and receptive language skills, the relational survey model; one of the survey models, was employed. The universe of the study is comprised of 5-6 years old children attending pre-school education institutions in the city of Kars and their parents. The sampling of the study consists of 165 children selected by means of the convenience sampling method and their parents. According to the findings of the current study, there is no significant relationship between the children's gender and their language development. There is a significant relationship between the children's perceptive and expressive language skills and their age and the number of siblings. There is no significant relationship between parents' attitudes and both the gender of the child and the gender of parents. Yet, the relationship between the number of children and parents' attitudes is significant. A significant relationship was found between democratic and authoritarian parental attitudes and children's language development.
\end{abstract}

Keywords Parental Attitudes, Receptive Language Skills, Expressive Language Skills, Parent-child Relationship

\section{Introduction}

Parents who have great influence on the lives of their children for a long time play a vital role in the formation of a healthy society. The emotional bonds that the child establishes with his/her parents in the pre-school period will have a significant impact on the personality traits he/she will have in the coming years. The experiences of the first years lay the basis of future behaviors. In this regard, the personality development of children whose basic needs such as care, love and protection are met will be in a positive direction. The quality of children's interaction with adults, the care they receive, the confidence and independence they can achieve are the vital elements that enable them to develop in a healthy manner. In addition, children gain basic knowledge, skills, attitudes and habits related to all developmental areas within the family environment. In this respect, the family is the main institution responsible for the care, development and education of the child [8-22-26-35-47]. Understanding the vital role that families play in children's lives has drawn attention to family characteristics. Variables such as the information that the family has on childrearing, the family's educational status, personality traits, socioeconomic levels, and the number of children the family has can influence the extent to which children can make use of educational opportunities offered within the family environment.

According to Çağdaş [11], the adequate use of educational opportunities offered by families to their children depends on healthy attitudes demonstrated by families towards their children. How healthy these attitudes will be depends to a great extent on the peaceful, balanced, respectful and affectionate relationships between the family members. However, parents' attitudes might not always be healthy. Due to various reasons such as upbringing in overtly authoritarian or tolerant conditions, coming from split families, being parents too early, some parents can develop negative attitudes towards their children.

One of the negative attitudes of parents to their children is the repressive-authoritarian attitude. Parents having this kind of attitude shape, control and evaluate their children's behaviors according to traditional criteria. They emphasize that children should obey authority and take punitive measures to ensure compliance [10]. In such an approach in 
which parents maintain control through coercion and avoidance of love, the child; instead of learning the proper behaviors, only changes his/her behaviors temporarily on the grounds of fear and apprehension. Children who grow up exposed to repressive and authoritarian attitudes of their parents may be rebellious or submissive despite their kind and careful behaviors. Moreover, the social relations and communication skills of these children are rather weak compared to their peers [3-24-62].

Another negative attitude of parents is their overprotective attitude. Parents having this attitude do everything themselves without making any demand from their children. Thus they do not make the child feel that he/she has a great capacity in terms of learning and being independent. Even though children who grow up with this attitude may feel loved, they feel insufficient, addictive and helpless in many subjects [29]. Overprotective parents' attitudes lead to creation of children who cannot make their own decisions, do not have abilities necessary to take initiatives, indicate their wishes by means of crying and are stubborn. In addition, these children who do not develop hand skills do not trust themselves and become clumsy [3-45].

The permitting parental attitude is another of the unhealthy attitudes that parents apply to their children. Parents adopting this kind of attitude shape their own behaviors according to the wishes of their children. They do not react to any of the child's wrong behaviors. For this reason, children who are not aware of their wrong behaviors expect other people around them to react like their parents and get disappointed [2]. Children who grow up exposed to this kind of attitude have difficulty in complying with social norms. They try to fulfill their demands by crying or screaming [43].

Democratic attitudes adopted by parents are healthy family attitudes which have positive effects on the child and the parents. Parents adopting this kind of attitude accept that the child has some rights. While determining rules and making decisions, they take the child's opinions into consideration [10]. Parents and children mutually value each other's views. By inculcating the sense of responsibility in children, they are expected to develop an independent personality. Strict restrictions are not exercised; children are provided with alternatives from which they can choose. Children who perceive their parents' attitudes as democratic have higher levels of self-concept than children who perceive their parents' attitudes as protective or authoritarian [36-48]. Much research has been done revealing the relationship between these attitudes of parents and the child's behaviors and developmental level.

Tokol [59] conducted a study to determine the relationship between the developmental characteristics of 3-6 years old children attending pre-school and of those not attending and their parents' attitudes. It was found that there is a positive relationship between the parents' education level and the children's attending pre-school and their developmental level. Moreover, the attitudes adopted by the parents are positively correlated with the children's linguistic, cognitive, psychomotor, social development levels and self-care ability.

Another study exploring parents' attitudes, children's social behaviors and perceptions of family relationships was conducted [40]. As a result of the study, it was concluded that the children of parents adopting positive parental attitudes have higher social behavior scores. The children of parents adopting negative attitudes on the other hand have lower social behavior scores when compared to the other children and they exhibit more aggressive behaviors.

Querido, Warner and Eyberg [50] investigated children's aggressive behaviors and parents' attitudes. In the study they conducted on 108 children of African-origin aged 3-6 years old, it was found that there is a positive correlation between children's aggressive behaviors and authoritarian and permitting parental attitudes and that there is a negative correlation between democratic attitudes and aggressive behaviors.

In the research investigating the relationship between the attitudes adopted by parents in upbringing their children and children's academic achievement, it has been emphasized that the children of parents adopting democratic attitudes are academically more successful than the children of parents adopting negative attitudes [37-46-63-65].

Aktaş Özkafacı [4] investigated the relationship between the child upbringing attitude adopted by the mother and the child's social skills level and found that there is a positive correlation between mothers' democratic attitudes and children's social skills; yet, there is a negative correlation between authoritarian, overprotective and permitting attitudes and children's social skills.

Altay and Güre [5] investigated the relationship between pre-school children's social competence and positive social behaviors and their mothers' parental attitudes. This study conducted with the participation of 344 mothers revealed that the girls' have more positive relationships with their peers and teachers than the boys. Moreover, the research results also showed that positive social behaviors of the children whose parents adopt democratic attitudes are more than those of the children whose parents adopt permitting attitudes.

Dursun [17] did a study on 233 5-6 years old children and their parents. The purpose of the study was to determine the parents' attitudes and behavioral problems of children and to analyze these attitudes and behavioral problems in relation to some family-related variables. At the end of the study, it was found that non-working parents are more protective than the other parents and the parents from low socio-economic status have more negative parental attitudes. It was also reported that the fathers have more democratic attitudes than the mothers and that there is 
a low correlation between the children's behavioral problems and parental attitudes.

Other studies revealing the relationship between parents' attitudes and children's development have been conducted by [6-28-54-56-52-61-64]. When these studies are reviewed, it is seen that they mostly focus on parents' attitudes and children's social, cognitive, affective development and academic learning. However, one of the areas which are affected from the attitudes adopted by parents is the linguistic development of children. Yet, there is a paucity of research exploring the relationship between parents' attitudes and children's linguistic development.

The linguistic development making important contributions to the development of children's academic and social skills throughout their lives is a process starting with the birth and continuing later [7-27-51]. The development of this skill from the birth onwards includes skills such as understanding the verbal language, expressing and understanding unwritten communicative applications. In this connection, two main linguistic components can be spoken of that are "receptive" and "expressive" languages. The skills needed to understand make up the receptive language and skills needed to express make up the expressive language. Receptive language refers to the child's receiving the language and behaving accordingly. Expressive language on the other hand refers to the child's being able to express himself/herself on the basis of his/her observations, emotions or feelings. When put into order of acquisition, the language skills can be listed as follows; listening, speaking, reading and writing. Listening and reading are considered to be receptive language skills and speaking and writing are considered to be expressive language skills [23-31-42-53].

When the relevant literature is reviewed, it is seen that there are many different factors influential on children's receptive and expressive language skills. [49] conducted a study to determine whether receptive and expressive language skills vary depending on the state of receiving pre-school education or not. At the end of the study, it was found that the children receiving pre-school education have better receptive and expressive language skills than the children not attending. According to [30] Family Literacy Project: Project EASE is a project in whose sampling only English speaking parents were included. Within the context of this project, families were given training about family-child interaction, development of receptive and expressive language skills and analysis of written expressions. It was concluded that this program created positive effects on the development of the children's receptive and expressive language skills. [38] investigated the effect of Montessori method on the development of children's language skills. They conducted their study on forty 5-6 years old children attending a pre-school education institution by dividing them into an experimental and a control group. As a result of this study, it was found that the language skills of the children having the Montessori education are better than those of the children not having this education. [15] conducted a study to determine whether pre-school children's expressive language skills vary depending on the variables of age, gender, socio-cultural characteristics and self-caring style. As a result of this study, it was found that the children's linguistic development varies depending on their age, self-caring style, mother's education status and socio-economic level. However, the children's linguistic development was found to be not varying significantly depending on father's education level.

Moreover, Erkan [21] investigated the effects of socio-economic level and education level, Acarlar [1] investigated the effects of age and gender, Denk [14] the effect of music, Storch and Whitehurst [57] the effect of home environment, Sénéchal and LeFevre [55] the effect of home experiences, Erdoğna, Şimşek Bekir, Erdoğan Aras [19] the effects of gender, length of attendance to pre-school, mother's education level, mother's job, the number of siblings and birth order and Dönmez and Güler [16] investigated the relationship between age and linguistic development. Linguistic development has important effects on the development of the child in other areas (cognitive, affective and social). In this respect, determination of the factors affecting linguistic development is of vital importance in terms of determining the responsibilities to be fulfilled by families, teachers and other adults [66]. Given that linguistic development has significant influence on the cognitive, affective and social development of children, it seems to be necessary to determine the factors affecting this development and to elicit their predictive effects. One of the factors affecting linguistic development is parental attitudes. Though there is some research looking at the family-related factors affecting linguistic development, there is no study focusing on the relationship between parental attitudes and linguistic development of children. In this regard, the purpose of the current study is to determine the relationship between parental attitudes and children's receptive and expressive language skills. The sub-problems of the study are as follows:

- Is there a significant relationship between children's receptive and expressive skills and gender?

- Is there a significant relationship between children's receptive and expressive skills and age?

- Is there a significant relationship between children's receptive and expressive skills and the number of siblings?

- Is there a significant relationship between parental attitudes and parents' gender?

- Is there a significant relationship between parental attitudes and children's gender?

- Is there a significant relationship between parental attitudes and the number of children? 
- Is there a significant correlation between the parents' attitudes and the children's perceptive and expressive language skills

\section{Method}

\subsection{Research Model}

In the current study investigating the relationship between parental attitudes and children's expressive and receptive language skills, the relational survey model; one of the survey models, was employed. According to [33], in the survey model generally used to describe a past or a present case as it was or it is, individuals or events which are subject to the study are investigated in their natural conditions without any intervention. In the relational survey model, it is intended to determine the existence and quality of the relationship between two or more variables.

\subsection{Universe and Sampling}

The universe of the study is comprised of 5-6 years old children attending pre-school education institutions in the city of Kars and their parents. The sampling of the study consists of 165 children selected by means of the convenience sampling method and their parents. In many disciplines such as education, psychology, medicine, rather than the random sampling method, the convenience sampling method is preferred. In the convenience sampling method, participants are not randomly selected from among the universe; instead, participants easy to reach are included (Warner, 2008). A total of 93 mothers (56.4\%) and 72 fathers $(43.6 \%)$ participated in the study. Of the participating parents, $59(35.8 \%)$ have one or two children, $30(18.2 \%)$ have three children and $23(13.9 \%)$ have four children. Of the participating children, $82(49.7 \%)$ are girls, $83(50.3 \%)$ are boys. The ages of children are between 60 and 77 months old.

\subsection{Data Collection Tools}

In order to collect data about the parents, "Parental Attitude Scale" was used and in order to collect data about the children, "Turkish Expressive and Receptive Language Skills Test (TIFALDi)" was used.

Parental Attitude Scale: The scale developed by [32] aims to determine the attitudes adopted by parents while growing up their children aged at 2-6 years old. The scale comprised of 46 items has four dimensions, which are "democratic attitude", "authoritarian attitude", "overprotective attitude" and "permitting attitude". In the reliability analyses conducted for the scale, Cronbach Alpha value was found to be .83 for the dimension of "democratic attitude", .76 for the dimension of "authoritarian attitude", .75 for the dimension of "overprotective attitude" and .74 for the dimension of "permitting attitude". The items of the Likert-type scale are presented in the form of behaviors. There are five response options for each item presented in the form of behaviors; "Always", "Often", "Sometimes", "Rarely" and "Never". For each item, only one of these response options should be marked. The response options are scored by assigning points ranging from "Always" 5 , to "Never" 1 . For each dimension, a total score is calculated; thus, a different total score is obtained for each dimension. Having a high score from a dimension means that the respondent adopts the behaviors stated in the related dimension.

Turkish Expressive and Receptive Language Skills Test (TIFALDi): The Turkish Expressive and Receptive Language Skills Test (TIFALDI) is a language test developed by [39] to evaluate children's word acquisition and utilization. The test comprised of two parts being receptive language and expressive language is administered to children aged at 2-12 years old. Administration time for each dimension is 20-35 minutes changing depending on age. Before the administration of the test, the child's chronological age needs to be calculated and from the point suitable for the chronological age, the test should be started. In each of the TIFFALDI cards individually administered and ordered from the simplest to the most difficult, there are four pictures one of which is the target. In the receptive language test, the child is required to find the target picture representing the target word; in the expressive language test, the child is required to tell what the picture shown by the implementer is. If the child gives the correct response, the correct column next to the correct word is ticked $(\sqrt{ })$. While the wrong answers or the statements outside the target are written in the column; the sign of absent $(\varnothing)$ is put next to the items which are not responded. The place corresponding to eight successive correct answers is taken as the threshold score. If the child makes a mistake without giving eight successive answers, then the evaluator goes back as long as required to determine the threshold score. If the child makes 8 mistakes out of 10 items (these eight mistakes may not be successive), then the test is ended and this point is set to be the ceiling age. The number of the correct answers given until the place of completion is added to the last item number of the obtained threshold score interval; thus, the raw score is found. The total raw score is then converted to either the standard score or the corresponding language score; thus, the data related to Turkish expressive and receptive language skills are elicited.

The standardization, validity and reliability studies of the Turkish Expressive and Receptive Language Skills Test (TIFALDI) were conducted by [39]. The Cronbach Alpha value was calculated to be .98 for the sub-test of receptive language vocabulary and it was found to be .99 for the sub-test of expressive language vocabulary. Within the context of the current study, the internal consistency coefficient was found to be .91 for the sub-test of receptive 
language vocabulary and .93 for the sub-test of expressive language vocabulary.

\subsection{Data Collection}

The data of the current study were separately collected for the parents and children. After granting the required permissions for the administration of the Parental Attitude Scale, the scale was administered to the participating parents. Before the administration of the scale, the participants were informed about the purpose of the study and how to complete the scale in the designated place and time. The parents completed the scale individually and then handed it out to the researcher in a closed envelope.

The Turkish Expressive and Receptive Language Skills Test used to collect data from the children was administered to the children individually by the researcher. Each child was asked to do what is required from them by first the instructions in the receptive test and then the instructions in the expressive test.

\subsection{Data Analysis}

The data collected in the current study were analyzed by using SPSS 16 statistical program package. Frequencies and percentages of the demographic features belonging to the participants are given in the table below. In order to determine whether the data show a normal distribution, Kolmogorov-Smirnov $\mathrm{Z}$ distribution test was run.

\begin{tabular}{ccc}
\hline Kolmogorov-Smirnov testi & Tutum & Alıcı ve ifade edici dil \\
\hline $\mathrm{N}$ & 165 & 165 \\
\hline Kolmogorov-Smirnov Z & 1.585 & 2.051 \\
\hline $\mathrm{P}$ & .013 & .000 \\
\hline
\end{tabular}

As the data did not show a normal distribution, non-parametric statistical techniques were used $\left(z_{\text {attitude }}=\right.$ $\left.1.585 ; z_{\text {receptive and expressive language }}=2.051 ; p<.05\right) .0 .05$ was set to be the significance level. In the comparison of the variables consisting of two categories, Mann-Whitney $U$ Test was used (receptive and expressive language-gender; parents' attitude-parents' gender; parents' attitude-children's gender); in the comparison of variables consisting of more than two variables, Kruskall Wallis Test was used.

As the variables do not have a normal distribution, Spearman correlation coefficient was used to determine the correlation between parents' attitudes and the children's receptive and expressive skills. According to [9], the correlation coefficient that is 1.00 means that there is a perfect positive correlation between the variables; -1.00 means that there is a perfect negative correlation and 0.00 means that there is no correlation. In the interpretation of the correlation, these threshold levels can be used: A correlation coefficient that is between 0.70 and 1.00 as an absolute value refers to a high correlation; 0.70 and 0.30 refers to a medium correlation and 0.30 and 0.00 refers to a low correlation.

\section{Findings}

In this section, the findings obtained in the current study are presented in the order of the sub-problems. Within the context of the first sub-problem of the study, Mann-Whitney U Test was run to determine whether the children's receptive and expressive skills vary significantly depending on the gender variable and the results are presented in Table 1.

As can be seen in Table 1, no significant difference is revealed by Mann-Whitney $U$ test (receptive language: $U=$ $3244.50 ; p>.05$; expressive language $U=3388.50 ; p>.05$ ). Thus, it can be argued that there is no significant relationship between the children's receptive and expressive language skills and gender.

Table 1. Mann-Whitney U Test Results Concerning the Children's Mean Scores Obtained from the TİFALDİ by Gender

\begin{tabular}{|c|c|c|c|c|c|c|}
\hline & Gender & $\mathrm{n}$ & Mean Rank & Sum of rank & $\mathrm{U}$ & $\mathrm{p}$ \\
\hline \multirow{2}{*}{ Receptive language } & Female & 87 & 84,71 & 7369,50 & \multirow{2}{*}{3244,50} & \multirow{2}{*}{,625 } \\
\hline & Male & 78 & 81,10 & 6325,50 & & \\
\hline \multirow{2}{*}{ Expressive language } & Female & 87 & 83,05 & 7225,50 & \multirow{2}{*}{3388,50} & \multirow{2}{*}{,988 } \\
\hline & Male & 78 & 82,94 & 6469,50 & & \\
\hline
\end{tabular}

Table 2. Kruskal Wallis Test Results Concerning the Children's Mean Scores Obtained from the TíFALDİ by Age

\begin{tabular}{|c|c|c|c|c|c|c|c|}
\hline & Age & $\mathrm{n}$ & Mean Rank & $\mathrm{Sd}$ & $\mathrm{X}^{2}$ & $\mathrm{p}$ & Difference \\
\hline \multirow{3}{*}{$\begin{array}{l}\text { Receptive } \\
\text { language }\end{array}$} & $60-65$ months & 42 & 58,36 & \multirow{3}{*}{2} & \multirow{3}{*}{15,37} & \multirow{3}{*}{, 000} & \multirow{3}{*}{$\begin{array}{l}1-2 \\
1-3\end{array}$} \\
\hline & $66-71$ months & 103 & 87,72 & & & & \\
\hline & 72-77 months & 20 & 92,13 & & & & \\
\hline \multirow{3}{*}{$\begin{array}{c}\text { Expressive } \\
\text { language }\end{array}$} & $60-65$ months & 42 & 63,61 & \multirow{3}{*}{2} & \multirow{3}{*}{9,52} & \multirow{3}{*}{,009 } & \multirow{3}{*}{$1-3$} \\
\hline & $66-71$ months & 103 & 88,90 & & & & \\
\hline & $72-77$ months & 20 & 93,35 & & & & \\
\hline
\end{tabular}


In order to determine whether there is a significant relationship between the children's receptive language and expressive language skills and the age variable, Kruskal Wallis test was administered and the results are presented in Table 2.

As can be seen in Table 2, the results of Kruskal Wallis Test related to the receptive and expressive language skills of the children from different ages revealed that the difference between the mean ranks of the age groups is statistically significant. That is, the children's receptive and expressive language skills vary significantly depending on the age variable (receptive language: $\mathrm{x}^{2}=$ $15.37 ; p<0.05$; expressive language $x^{2}=9.52 ; p<0.05$ ). In order to determine between which groups the significant difference exists as a result of Kruskal Wallis Test, complementary comparison techniques were used. As there is no special technique for this purpose, Mann-Whitney U test, normally used in paired-comparisons, was employed. As a result of this analysis, the difference in the receptive language skills was found to be in favor of 66-71 and 72-77 months old children $(\mathrm{U}=1303.50 ; \quad \mathrm{z}=3.781 ; .00$ and $\mathrm{U}=244.50$; $\mathrm{z}=2.658 ; .00)$. That is, the language skill standard scores of the 66-77 months old children are higher than those of the 60-65 months old children. In a similar manner, the difference in the expressive language skills is in favor of the 72-77 months old children ( $\mathrm{U}=1432.50 ; \mathrm{z}=3.208 ; .00)$. That is, older children's expressive language standard scores are higher than those of the younger children.

The results of Kruskal Wallis Test run to determine whether there is a significant relationship between the children's perceptive and expressive language skills and the number of siblings are presented in Table 3 .

As can be seen in Table 3, the children's both perceptive and expressive language skills vary significantly depending on the number of siblings (receptive language: $\mathrm{X}^{2}=45.42 ; \mathrm{p}<0.05 ;$ expressive language $\mathrm{X}^{2}=26.16$; $\mathrm{p}<0.05)$. In order to determine between which groups the significant different exists as a result of Kruskal Wallis Test, complementary comparison techniques were used. As a result of Mann-Whitney U test conducted for this purpose, the difference in the receptive language skills was found to be in favor of the children having more siblings ( $\mathrm{U}=766.00$; $\mathrm{z}=4.688 ; .00$ and $\mathrm{U}=351.00 ; \mathrm{z}=4.662 ; .00 ; \mathrm{U}=223.500$; $\mathrm{z}=4.736 ; .00$ ). That is, the receptive skills standard scores of the children having greater number of siblings are better than the children having fewer or no siblings. When the difference in the children's expressive language skills was examined, similar findings were obtained and the difference was found to be in favor the children having more siblings again $(\mathrm{U}=931.00 ; \mathrm{z}=3.721 ; .00 ; \mathrm{U}=293.00$; $z=3.611 ; .00$ and $U=347.50 ; z=3.449 ; .00)$. That is, the expressive skills standard scores of the children having more siblings are better than the children having fewer or no siblings.

Within the context of another sub-problem of the current study, Mann-Whitney U test was conducted to determine whether there is a significant relationship between the parents' attitudes and gender and the results are presented in Table 4.

Table 3. Kruskal Wallis Test Results Concerning the Cildren's Mean Scores Obtained from the TíFALDİ by Number of Siblings

\begin{tabular}{|c|c|c|c|c|c|c|c|}
\hline & $\begin{array}{c}\text { Number of } \\
\text { siblings }\end{array}$ & $\mathrm{n}$ & Mean Rank & $\mathrm{Sd}$ & $\mathrm{X}^{2}$ & $\mathrm{p}$ & Difference \\
\hline \multirow{4}{*}{ Receptive language } & no siblings & 59 & 52,72 & \multirow{4}{*}{3} & \multirow{4}{*}{45,42} & \multirow{4}{*}{, 000} & \multirow{4}{*}{$\begin{array}{l}1-2 \\
1-3 \\
1-4\end{array}$} \\
\hline & 1 siblings & 53 & 88,09 & & & & \\
\hline & 2 siblings & 30 & 104,85 & & & & \\
\hline & 3 siblings & 23 & 120,43 & & & & \\
\hline \multirow{4}{*}{ Expressive language } & no siblings & 59 & 61,24 & \multirow{4}{*}{3} & \multirow{4}{*}{26,16} & \multirow{4}{*}{, 000} & \multirow{4}{*}{$\begin{array}{l}1-2 \\
2-4 \\
1-4\end{array}$} \\
\hline & 1 siblings & 53 & 84,16 & & & & \\
\hline & 2siblings & 30 & 99,60 & & & & \\
\hline & 3siblings & 23 & 114,50 & & & & \\
\hline
\end{tabular}

Table 4. Mann-Whitney U Test Results Concerning the Parent's Mean Scores Obtained from the Parental Attitude Scale by Gender

\begin{tabular}{|c|c|c|c|c|c|c|}
\hline Parents' Attitudes & Gender & $\mathrm{n}$ & $\begin{array}{l}\text { Mean } \\
\text { Rank }\end{array}$ & Sum of rank & U & $\mathrm{p}$ \\
\hline \multirow{2}{*}{ Democratic } & Female & 93 & 81,25 & 7556,00 & \multirow{2}{*}{3185,00} & \multirow{2}{*}{, 592} \\
\hline & Male & 72 & 85,26 & 6139,00 & & \\
\hline \multirow{2}{*}{ Authoritarian } & Female & 93 & 80,17 & 7456,00 & \multirow{2}{*}{3,08} & \multirow{2}{*}{,387 } \\
\hline & Male & 72 & 86,65 & 6239,00 & & \\
\hline \multirow{2}{*}{ Protective } & Female & 93 & 81,90 & 7616,50 & \multirow{2}{*}{3,24} & \multirow{2}{*}{,736 } \\
\hline & Male & 72 & 84,42 & 6078,50 & & \\
\hline \multirow{2}{*}{ Permitting } & Female & 93 & 80,12 & 7451,50 & \multirow{2}{*}{3,08} & \multirow{2}{*}{,378 } \\
\hline & Male & 72 & 86,72 & 6243,50 & & \\
\hline
\end{tabular}


As can be seen in Table 4, as a result of Mann-Whitney Test, no significant difference was found (democratic: $U=$ 3185.00, $p>.05$; authoritarian: $U=3.08, p>.05$; protective: $U=3.24, p>.05$; permitting; $U=3.08, p>.05$ ). Thus, there is no significant relationship between the parents' attitudes and gender.

Table 5. Mann-Whitney U Test Results Concerning the Parent's Mean Scores Obtained from the Parental Attitude Scale by Children's Gender

\begin{tabular}{|c|c|c|c|c|c|c|}
\hline Parents' Attitudes & Gender & $\mathrm{n}$ & Mean Rank & Sum of rank & $\mathrm{U}$ & $\mathrm{p}$ \\
\hline \multirow{2}{*}{ Democratic } & Female & 81 & 75,50 & 6115,50 & \multirow{2}{*}{2794,50} & \multirow{2}{*}{, 062} \\
\hline & Male & 83 & 89,33 & 7414,50 & & \\
\hline \multirow{2}{*}{ Authoritarian } & Female & 81 & 76,18 & 6170,50 & \multirow{2}{*}{2,85} & \multirow{2}{*}{, 092} \\
\hline & Male & 83 & 88,67 & 7359,50 & & \\
\hline \multirow{2}{*}{ Protective } & Female & 81 & 74,09 & 6001,00 & \multirow{2}{*}{2,68} & \multirow{2}{*}{, 052} \\
\hline & Male & 83 & 90,71 & 7529,00 & & \\
\hline \multirow{2}{*}{ Permitting } & Female & 81 & 79,35 & 6427,50 & \multirow{2}{*}{3,10} & \multirow{2}{*}{,400 } \\
\hline & Male & 83 & 85,57 & 7102,50 & & \\
\hline
\end{tabular}

Mann-Whitney U Test was run to determine whether there is a significant relationship between the parents' attitudes and children's gender and the results are presented in Table 5.

As can be seen in Table 5, no significant difference emerged as a result of Mann-Whitney $U$ test (democratic: $U=$ 2794.50, $p>.05$; authoritarian: $U=2,85, p>.05$; protective: $U=2.68, p>.05$; permitting; $U=3.10, p>.05$ ). Thus, there is no significant relationship between the parents' attitudes and children's gender.

Kruskal Wallis Test was used to determine whether there is a significant relationship between the parents' attitudes and the number of children and the results are presented in Table 6 .

Table 6. Kruskal Wallis Test Results Concerning the Cildren's Mean Scores Obtained from Parental Attitude Scale by Number of Children

\begin{tabular}{|c|c|c|c|c|c|c|c|}
\hline & Number of children & $\mathrm{n}$ & Mean Rank & $\mathrm{Sd}$ & $\mathrm{X}^{2}$ & $\mathrm{p}$ & difference \\
\hline \multirow{4}{*}{ Democratic } & 1 & 59 & 72,11 & \multirow{4}{*}{3} & \multirow{4}{*}{14,02} & \multirow{4}{*}{003} & \multirow{4}{*}{$1-4$} \\
\hline & 2 & 53 & 84,51 & & & & \\
\hline & 3 & 30 & 77,10 & & & & \\
\hline & 4 & 23 & 115,15 & & & & \\
\hline \multirow{4}{*}{ Authoritarian } & 1 & 59 & 88,99 & \multirow{4}{*}{3} & \multirow{4}{*}{5,15} & \multirow{4}{*}{, 161} & \\
\hline & 2 & 53 & 86,02 & & & & \\
\hline & 3 & 30 & 81,07 & & & & \\
\hline & 4 & 23 & 63,20 & & & & \\
\hline \multirow{4}{*}{ Protective } & 1 & 59 & 80,03 & \multirow{4}{*}{3} & \multirow{4}{*}{5,36} & \multirow{4}{*}{, 147} & \\
\hline & 2 & 53 & 74,53 & & & & \\
\hline & 3 & 30 & 92,03 & & & & \\
\hline & 4 & 23 & 98,35 & & & & \\
\hline \multirow{4}{*}{ Permitting } & 1 & 59 & 80,90 & \multirow{4}{*}{3} & \multirow{4}{*}{7,20} & \multirow{4}{*}{,066 } & \\
\hline & 2 & 53 & 95,26 & & & & \\
\hline & 3 & 30 & 79,55 & & & & \\
\hline & 4 & 23 & 64,63 & & & & \\
\hline
\end{tabular}

As can be seen in Table 6, there is a statistically significant relationship between the democratic parental attitudes and the number of children $\left(\mathrm{X}^{2}=14.02 ; \mathrm{p}<0.05\right)$. No significant difference was found between the other parental attitudes and the number of children (authoritarian: $\mathrm{X}^{2}=5.15, \mathrm{p}>.05$; protective: $\mathrm{X}^{2}=5.36, \mathrm{p}>.05$; permitting; $\mathrm{X}^{2}=7.20, \mathrm{p}>.05$ ). In order to determine the source of the difference, Mann-Whitney $U$ test was conducted revealing that this difference is in favor of the parents having more children $(\mathrm{U}=339.00 ; \mathrm{z}=3.509 ; .00)$. That is, parents having more children are more democratic than the parents having fewer children.

In the current research, the correlation between the parents' attitudes and the children's perceptive and expressive language skills was revealed through the Spearman Brown Rank Differences correlation coefficient and the results are presented in Table 7. 
Table 7. Correlation between the Parents' Attitudes and the Children's Perceptive and Expressive Language Skills

\begin{tabular}{ccccc}
\hline Parents' attitudes & Language Skills & $\mathrm{N}$ & Correlation Coefficient & Sig. (2-tailed) \\
\hline \multirow{2}{*}{ Democratic } & Receptive language & 165 &, 350 &, 000 \\
& Expressive language & 165 &, 602 &, 000 \\
\hline \multirow{2}{*}{ Authoritarian } & Receptive language & 165 &,- 172 &, 027 \\
\cline { 2 - 5 } & Expressive language & 165 &,- 183 &, 019 \\
\hline \multirow{2}{*}{ Protective } & Receptive language & 165 &,- 107 &, 172 \\
\cline { 2 - 5 } & Expressive language & 165 &,- 055 &, 484 \\
\hline \multirow{2}{*}{ Permitting } & Receptive language & 165 &,- 094 &, 231 \\
\cline { 2 - 5 } & Expressive language & 165 &,- 154 &, 049 \\
\hline
\end{tabular}

As can be seen in Table 7, the children's receptive and expressive language skills vary significantly depending on their parents' attitudes. According to the findings of the current study, there is a medium, positive and significant correlation between the democratic parental attitudes and the children's both receptive and expressive language skills $(\mathrm{r}=.350$ and $\mathrm{p}<0.01 ; \mathrm{r}=.602$ and $\mathrm{p}<0.01)$. Thus, it can be argued that with increasing democratic parental attitude, children's receptive and expressive language skills also improve. There is also a negative and significant correlation between authoritarian parents' attitudes and children's receptive and expressive language skills $(\mathrm{r}=-.172$ and $\mathrm{p}<0.01 ; \mathrm{r}=-.183$ and $\mathrm{p}<0.01)$. That is, with the parents' increasing authoritarian attitudes, the children's receptive and expressive language skills develop less. As can be seen in Table 7, though there is a low and negative correlation between the parents' protective and permitting attitudes and the children' receptive and expressive language skills, this difference is not statistically significant (protective $\mathrm{r}=-.107$ and $\mathrm{p}>0.01 ; \mathrm{r}=-.055$ and $\mathrm{p}>0.01$; permitting $\mathrm{r}=-.094$ and $\mathrm{p}>0.01 ; \mathrm{r}=-.154$ and $\mathrm{p}>0.01)$.

\section{Discussion and Conclusions}

In the current study investigating the relationship between parental attitudes and children's receptive and expressive language skills, no significant correlation was found between the children's receptive and expressive language skills and gender. When the relevant literature is reviewed, it is seen that there are many studies reporting findings parallel to this finding of the current study. [67] investigated the receptive language skills of children aged 30-47 months old and found that gender does not lead to significant differences in the children's understanding of linguistic structures and their vocabulary repertoire. In another study comparing the receptive and expressive language skills of the children attending a pre-school institution and those of the children not attending a pre-school institution, no significant difference based on gender was found [49]. In the study in which [20] investigated the relationship between the language development levels of 5-6 years old children and their social acceptance levels, it was found that the children's scores taken from the Peabody Picture Word Test do not vary significantly by gender. Other studies reporting that the gender variable does not lead to significant differences in children's linguistic development are the studies by [1], [12], [18], [19], [25], [58]. When the findings of the current study are evaluated in light of the relevant literature, it can be argued that the children's gender does not lead to a significant difference because the participating children are in an interaction with similar stimuli in similar environments.

Within the context of another sub-problem of the study, it was determined that the age variable is influential on the children's receptive and expressive language skills (receptive language: $\mathrm{X}^{2}=15.37 ; \mathrm{p}<0.05 ;$ expressive language $\left.\mathrm{x}^{2}=9.52 ; \mathrm{p}<0.05\right)$. As a result of the analysis conducted to determine between which groups the difference exists, it was elicited that the receptive and expressive language skills of the older children are better than those of the younger children. With increasing age, the development of cognitive processes accelerates. This development makes it easier for children to understand more complex sentence structures and contributes to the development of their receptive language skills [44]. [15] investigated the relationship between the expressive language skills of the children attending pre-school education institutions and age, gender, socio-cultural characteristics and self-care styles and concluded that the children's expressive language skills vary significantly depending on age, self-care style, mother's education level and socio-economic level. [16] investigated the linguistic development of children by grouping them according to their ages as 48-54, 55-60, 61-66 and 67-72 months old. As a result of this research, it was found that the children's receptive language skills vary significantly depending on the age factor and that in all the sub-themes, there is a significant age-dependent increase. In a study by [41], it was found that the children's sentence comprehension improves with increasing age. Thus, the findings in the literature seem to support the current study. With 
increasing age, the number of words used by children also increases. Children with wide repertoire of vocabulary can both express themselves and understand what is told to them more easily. In this connection, the repertoire of vocabulary developing with increasing age can help children enhance their receptive and expressive language skills.

It was also found that the participating children's receptive and expressive language skills vary significantly depending on the number of siblings (receptive language: $\mathrm{X}^{2}=45.42 ; \mathrm{p}<0.05 ;$ expressive language $\mathrm{X}^{2}=26.16$; $\mathrm{p}<0.05)$. As a result of the analysis to determine between which groups the difference exists, it was concluded that the receptive and expressive language skills standard scores of the children with more siblings are higher than those of the children with fewer or no siblings. With the increasing number of individual in the family, the number of people children can interact also increases. The children having siblings may have a richer environment in terms of stimuli that can enable them both to communicate and to take model. In an environment having more opportunities to listen and speak, children's receptive and expressive skills develop more. The difference found in the current study in relation to the number of siblings may have resulted from these factors.

In the current study, no significant correlation was found between the parents' attitudes and both the parents' gender and the children's gender. When the relevant literature is examined, it is seen that there are some studies showing that there is no correlation between parents' attitudes and parents' gender. [34] investigated the child raising attitudes of the parents having children attending elementary education and found that mothers and fathers have similar attitudes. As a result of the current study, no significant correlation was also found between parents' attitudes and children's gender. This finding is also supported by some studies in the literature. In a study by [4] investigating the relationship between the child raising attitudes of the mothers having six year old children and the children's social skill levels, it was found that there is no relationship between the mothers' attitudes and the children's gender. In a similar manner, [13] researched the attitudes of mothers from low and high socio-economic levels. As a result of the study, it was found that the children's gender is not influential on the mothers' child raising attitudes. [60] investigated the relationship between parents' attitudes, children's social competence and related variables and concluded that there is no relationship between the parents' attitudes and the children's gender.

Within the context of another sub-problem requiring the investigation of the relationship between parents' attitudes and the number of children, a significant relationship was found between democratic parental attitudes and the number of children; yet, no significant relationship was found between the other parental attitudes and the number of children (democratic: $x^{2}=14.02, p<0.05$; authoritarian: $\mathrm{X}^{2}=5.15, \mathrm{p}>.05$; protective: $\mathrm{x}^{2}=5.36, \mathrm{p}>.05$; protective;
$\left.\mathrm{X}^{2}=7.20, \mathrm{p}>.05\right)$. It was determined that the parents having four children have more democratic attitudes than the parents having one child. In this regard, it can be claimed that the parents having more than one child may have to treat their children equally not to make them feel discriminated. Moreover, it can be maintained that parents having more children pay greater attention to their children's opinions, avoid attitudes and behaviors that may mean comparing children; accordingly, they adopt democratic attitudes more.

The main research question is related to the relationship between the parents' attitudes and the children's receptive and expressive language skills and this relationship was determined by using Spearman correlation coefficient. The findings of the study revealed that there is a positive, medium and significant correlation between the democratic parental attitudes and the children's both receptive and expressive language skills. In other words, with increasing democratic parental attitude, the children's receptive and expressive language skills develop more. A negative and significant correlation was found between the authoritarian parental attitudes and the children's both receptive and expressive language skills. That is, with increasing authoritarian parental attitudes, the children's receptive and expressive language skills improve less. No significant correlation was found between the parents' protective and permitting attitudes and the children's receptive and expressive language skills. [59] compared children's developmental characteristics and parents' attitudes and found a significant correlation between the democratic parental attitudes and the children's linguistic, cognitive, psycho-motor, social development and self-care skills. As in families adopting democratic attitudes, children are provided with more opportunities to listen, to express themselves, to participate in decision-making process, to take responsibility, children live such experiences more frequently. Through these interactions, children feel the need for more use of language. However, families adopting repressive or authoritarian attitudes do not provide many opportunities for their children. Children are only expected to obey the instructions given by their parents. In this respect, the opportunities offered to children are influential on the relationship between these two variables of the study. In light of the findings of the current study, following suggestions can be made: The current study was conducted by using the quantitative design. Qualitative studies carrying out an in-depth investigation of parents' attitudes and their children's receptive and expressive attitudes can make important contributions to the field. The current study was conducted on a limited sampling and in relation to some certain variables. Further research can be done on larger samplings and with different variables and the results can be compared. The research findings should be shared with parents so that parents' awareness of the issue can be raised. 


\section{REFERENCES}

[1] Acarlar, F. (1991). 2,5-4 yaşlar arasındaki Türk çocuklarının dil yapılarının incelenmesi. Yayınlanmamış yüksek lisans tezi, Hacettepe Üniversitesi, Ankara.

[2] Ağır, M., Akbağ, M., Aydın, B., Tuzcuoğlu, S., \& Yaycı, L. (2005). Gelişim ve Öğrenme. İstanbul: Nobel Yayınevi.

[3] Akın, Yeliz (2002). Altı yaş grubu çocuklarında başkasının bakış açısını alma yetisi üzerinde eğitici drama programının ve aile tutumlarının etkisinin incelenmesi. Yayınlanmamış Yüksek lisans tezi, Marmara Üniversitesi, İstanbul.

[4] Aktaş Özkafacı, A. (2012). Annenin çocuk yetiştirme tutumu ile çocuğun sosyal beceri düzeyi arasındaki ilişkinin incelenmesi. Ar-El Üniversitesi, İstanbul.

[5] Altay, F.B, Güre, A. (2012). Okul öncesi kuruma (devlet-özel) devam eden çocukların sosyal yeterlik ve olumlu sosyal davranışları ile annelerinin ebeveynlik stilleri arasındaki ilişkiler. Kuram ve Uygulamada Eğitim Bilimleri, 12 (4), 2699-2718.

[6] Aunola, K.,\& Nurmi, J. E. (2005). The role of parenting styles in children's problem behavior. Child Development, 76 (6), 1144-1159.

[7] Bonica, C., Arnold, D.H., Fisher, P.H., Zeljo, A., ve Yershova, K. (2003). Relational aggression, relational victimization, and language development in preschoolers. Social Development, 12 (4), 551-562.

[8] Bornstein, L. \& Bornstein, M.H. (2007). Parenting Styles and Child Social Development. Encyclopedia on Early Childhood Development. 1-4. Montreal, Quebec, Canada: Centre of Excellence for Early Childhood Development and Strategic Knowledge Cluster on Early Child Development. Online avaible http://www.child-encyclopedia.com

[9] Büyüköztürk, Ș. (2011). Sosyal Bilimler İçin Veri Analizi El Kitabı (14. bs.). Ankara: Pegem Akademi Yayıncılık.

[10] Cole, M.; Cole, S. (2001). The Devolepment of Children. United States of America: Worth Publishers.

[11] Çağdaş, A. (2012). Anne-Baba-Çocuk İletişimi. Ankara: Eğiten Kitap.

[12] Damar, M. (2007). İsviçre'de yaşayan altı yaş Türk çocuklarının dil kazanımlarına yönelik geliştirilen Türkçe dili etkinlikleri gözlem formu geçerlik ve güvenirlik çalıșması. Yayınlanmamıș Doktora lisans tezi, Gazi Üniversitesi, Ankara.

[13] Demiriz, S. ve Öğretir, A.D. (2007). Alt ve üst sosyoekonomik düzeydeki 10 yaş çocuklarının anne tutumlarının incelenmesi. Kastamonu Eğitim Dergisi. 15(1),105-122.

[14] Denk, D. (2000). Anaokuluna devam eden 6 yaş grubundaki çocukların alıcı dil gelişim düzeylerine müzik eğitiminin etkisinin incelenmesi. Yayınlanmamış yüksek lisans tezi, Hacettepe Üniversitesi, Ankara.

[15] Dereli, E. (2003). Okul öncesi eğitime devam eden 4-6 yaş arasındaki çocukların ifade edici dil düzeylerinin incelenmesi (Konya ili örneği). Yayınlanmamış yüksek lisans tezi, Selçuk Üniversitesi, Konya.

[16] Dönmez, N. ve Güler T. (2007). 48-72 aylar arasındaki Türk çocuklarının alıcı dil yapılarının incelenmesi. Eğitim Araştırmaları Dergisi, 27, 83-96.

[17] Dursun, A. (2010). Okul öncesi dönemdeki çocukların davranıs problemleriyle anne-baba tutumları arasındaki ilişkinin incelenmesi. Yayınlanmamış yüksek lisans tezi, Dokuz Eylül Üniversitesi, İzmir.

[18] Erdemir, N. (2001). 12-30 aylar arasındaki Türk çocuklarının dil yapılarının anlamsal yönden incelenmesi. Yayımlanmamış Doktora Tezi, Hacettepe Üniversitesi, Ankara.

[19] Erdoğan, S. , Şimşek Bekir . H. , Erdoğan Aras A. (2005). Ankara'nın alt sosyoekonomik bölgelerinde ana sınıfına devam eden 5-6 yaş çocuklarının dil gelişim düzeylerine bazı faktörlerin etkisinin incelenmesi. Çukurova Üniversitesi Sosyal Bilimler Dergisi, 1, 231-246.

[20] Ergin, B. (2007). 5-6 yaş çocuklarının dil gelişim düzeyleri ile sosyal kabul durumları arasındaki ilişkinin incelenmesi. Yüksek lisans tezi, Selçuk Üniversitesi, Konya.

[21] Erkan, P. (1990). Sosyoekonomik ve ĕ̌itim düzeyleri farkl olan ailelerin 48-60 aylar arasındaki çocukların dil yapılarının incelenmesi. Yayınlanmamış yüksek lisans tezi, Hacettepe Üniversitesi, Ankara.

[22] Gardiner, H. W. \& Gander, M. J. (2010). Çocuk ve ergen gelişimi. (Ali Dönmez, Bekir Onur, Nermin Çelen, çev.) Ankara: İmge Kitabevi.

[23] Gordon, A. M., \& Browne, K. W. (2011). Beginnings and Beyond Foundations in Early Childhood Education (8th ed.). Belmont: Wadsworth Cengage Learning.

[24] Günalp, A. (2007). Farklı anne baba tutumlarının okul öncesi eğitim çağındaki çocukların özgüven duygusunun gelişimine etkisi (Aksaray ili örneği). Yüksek lisans tezi, Selçuk Üniversitesi, Konya.

[25] Gürocak Ünal, S. (2007). Anasınıfina devam eden 60-72 ay çocukların dil gelişimi ve ince motor gelişimi açısından değerlendirilmesi. Yüksek lisans tezi, Abant İzzet Baysal Üniversitesi, Bolu.

[26] Gürsimsek, İ. (2002). Etkin Ögrenme ve Aile Katılımı. İ. Gürsimsek (Yay. Haz.), DEÜ Anaokulu/anasınıf Ögretmen El Kitabı içinde (25-43). İstanbul :Ya-pa.

[27] Güven, N. ve Bal, S. (2004). Dil Gelişimi ve Eğitimi, 0-6 Yaş Dönemindeki Çocuklar İçin Destekleyici Etkinlikle. (3. bs), İstanbul: Epsilon Yayıncılık.

[28] Hart, H. C., Nelson, A.D., Robinson, C. C., Olsen, F. S., Mcneilly-Choque, K. (1998). Overt and relational aggression in Russian nurseryschool- age children: parenting style and marital linkages. Developmental Psychology, 34 (4), 687-697.

[29] Humphreys, T. (2002). Çocuk eğitiminin anahtarı: özgüven (T. Anapa, çev.), İstanbul: Epsilon Yayınevi.

[30] Jordan, G, E., Snow, C.E. \& Porche, M, V. (2000). Project EASE: The effect of a family literacy project on kindergarten students' early literacy skills. Reading Research Quarterly, 35(4), 524-546.

[31] Kandır, A., Uyanık, Ö., Yazıcı, E., Can-Yaşar, M., İnal, G., Ceylan S., Yazıcı, Z., Çalıșandemir, F., Özbey, S. (2012). Dil etkinlikleri. Ankara: Efil Yayınevi. 
[32] Karabulut Demir, E., Sendil, G. (2008). Ebeveyn tutum ölçeği (ETÖ). Türk Psikoloji Yazıları, 11 (21), 15-25.

[33] Karasar, N. (2009). Bilimsel Araştırma Yöntemi. Ankara: Nobel Yayın Dağıtım.

[34] Kaya, A. (2010). İköğretim öğrencilerinin anne-babalarının çocuk yetiştirme tutumlarının kişilik özelliklerine göre değișkenliğinin incelenmesi. Yayınlanmamış yüksek lisans tezi, Maltepe Üniversitesi, İstanbul.

[35] Kaya, S. (2014). Çocukluk dönemi örselenme yaşantıları ölçeği kısa formu'nun Türkçeye uyarlanması. Yüksek lisans tezi, Muğla Sitkı Koçman Üniversitesi, Muğla.

[36] Kaya, M. (1998). Ondokuz mayıs üniversitesi öğrencilerinin benlik tasarımları düzeyi. Yüksek lisans tezi, Ondokuz Mayıs Üniversitesi, Samsun.

[37] Kaya, A., Bozaslan, H., Genç, G. (2012). Üniversite öğrencilerinin anne-baba tutumlarının problem çözme becerilerine, sosyal kayg1 düzeylerine ve akademik başarılarına etkisi. Dicle Üniversitesi Ziya Gökalp Eğitim Fakültesi Dergisi, 18, 208-225.

[38] Kayıl1, G., Koçyiğit, S., Erbay, F. (2009). Montessori yönteminin beş - altı yas çocuklarının alıcı dil gelişimine etkisinin incelenmesi. Türkiyat Araştırmaları Dergisi, 26, 347-355.

[39] Kazak Berument, S. ve Gül Güven, A. (2010). TİFALDİ : Türkçe ifade edici ve alıcı dil testi. Ankara: Türk Psikologlar Derneği.

[40] Laibe, D., Carlo, G., Torquati, J., \& Ontai, L. (2004). Children's perception of family relationships as assessed in a doll story completion task: Links to parenting, social competence, and externalizing behavior. Social Development, 13 (4), 551-569.

[41] Lempert, H. (1985). Preschool children's sentence comprehension: strategies with respectto animacy. Journal of Child Language, 12 (1), 79-93.

[42] Lovaas, I. O. (2005). Ben Kitabı: Gelişimsel Yetersizliği Olan Çocuklara Öğretme Rehberi Ístanbul: Sistem Yayıncilık.

[43] Marsiglia, C., Walczyk, J., Buboltz, W. \& Griffith-Ross, D. (2006). Impact of parenting styles and locus of control on emerging adults' psychosocial success. Journal of Education and Human Development, 1, 1-11.

[44] Musolino, J. (2002). The semantics and acquistion of number words: integrating linguistic and developmental perspectives. Cognition, 93 (2), 1-41.

[45] Navaro, L. (1989). Aşırı Koruyuculuğun Çocuk Eğitimine Etkileri. İstanbul: Ya-Pa Yayınları.

[46] Nimsi, E. (2006). Ilköğretim ikinci sınıf öğrencilerinin ana-baba tutumları ile okul başarıları ve sınıf içi etkinlik düzeylerinin karşılaștırılması. Yayınlanmamış yüksek lisans tezi, Uludağ Üniversitesi, Bursa.

[47] Oktay, A.(1991). Türkiye'de okul öncesi eğitimin gelişimi. B. Onur (Yay. Haz.). 2. Ulusal Çocuk Kültürü Kongresi kitabı içinde (s. 289-298), Ankara.

[48] Özgüven, İ. E. (2001). Ailede Illetişim ve Yaşam. Ankara:
Pdrem yayınları.

[49] Öztürk, H. (1995). Okul öncesi eğitim kurumlarına giden ve gitmeyen ilkokul birinci sınıf öğrencilerinin alıcı ve ifade edici dil düzeyleri. Yüksek lisans tezi, Gazi Üniversitesi, Ankara.

[50] Querido, J. G., Warner, T. D., \& Eyberg, S. M. (2002). Parenting styles and child behavior in African American families of preschool children. Journal of Clinical Child Psychology, 31 (2), 272-277.

[51] Rudasill, K.M. (2011). Child temperament, teacher-child interactions, and teacher-child relationships: A longitudinal investigation from first to third grade. Early Childhood Research Quarterly, 26 (2), 147-156.

[52] Russel, A., Hart, C. H., Robinson, C. C., \& Olsen, S. F. (2003). Children's sociable and aggressive behaviour with peers: A comparison of the US and Australia, and contributions of temperament and parenting styles. International Journal of Behavioral Development, 27 (1), 74-86.

[53] San Bayhan, P. Ve Artan, İ. (2007), Çocuk Gelişimi ve Eğitimi, İstanbul: Morpa Kültür Yayınları.

[54] Sarı, E. (2007). Anasınıfina devam eden 5-6 yaşgrubu çocukların, annelerinin çocuk yetiştirme tutumlarının, çocuğun sosyal uyum ve becerilerine etkisinin incelenmesi. Yayınlanmamış Yüksek Lisans Tezi, Gazi Üniversitesi, Ankara.

[55] Sénéchal, M. \& LeFevre, J. (2002). Parental involvement in the development of children's reading skill: A 5-year longitudinal study. Child Development, 73(2), 445-460.

[56] Synder, J. Stoolmiller, M., Wilson, M., \& Yamamoto, M. (2003). Child anger regulation, parental responses to children's anger displays, and early child antisocial behavior. Social Development, 12 (3), 335-360.

[57] Storch, S. A. \& Whitehurst, G. J. (2001). The role of family and home in the literacy development of children from low-income backgrounds. New Directions for Child and Adolescent Development, 92, 53-71.

[58] Tepeli, Y. ve Karadeniz, H.K. (2013). Otizmli ve normal gelişim gösteren çocukların alıcı dil becerilerinin farklı değişkenler açısından incelenmesi. Dil ve Edebiyat Eğitimi Dergisi, 2 (6), 73-89.

[59] Tokol, O. (1996). Okulöncesi eğitim kurumlarına devam eden ve etmeyen 3-6 yaş çocukların gelişim özellikleri ve anne-baba tutumlarının karşılaştırılması. Yayınlanmamış yüksek lisans tezi, Marmara Üniversitesi, İstanbul.

[60] Turner, P.H \& Haris, M.B (1984). Parental attitudes and preschool children's social competence. The Journal of GeneticPsychology: Research and Theory on Human Development, 144 (1), 105-113.

[61] Yağmurlu, B., Sanson, A. ve Köymen, S. B. (2005). Ebeveynlerin ve çocuk mizacının olumlu sosyal davranış gelişimine etkileri: zihin kuramının belirleyici rolü. Türk Psikoloji Dergisi, 20 (55), 1-20.

[62] Yavuzer, H. (2000). Ana-Baba ve Çocuk. 13. Bask1. İstanbul: Remzi Kitapevi.

[63] Yıldırım, İ. (2006). Akademik başarının yordayıcısı olarak 
gündelik s1kıntılar ve sosyal destek. Hacettepe Üniversitesi Ĕgitim Fakültesi Dergisi, 30, 258-267.

[64] Yılmaz, A. (2001). Eşler arasındaki uyum, anne-baba tutumu ve benlik algısı arasındaki ilişkilerin gelişimsel olarak incelenmesi. Türk Psikoloji Dergisi, 16 (47), 1-24.

[65] Y1lmazer, Y. (2007). Anne-baba tutumları ile ilköğretim ikinci kademe ögrencilerinin okul başarısı ve özerkliklerinin gelişimi arasındaki ilişkinin incelenmesi. Yayınlanmamış yüksek lisans tezi, Hacettepe Üniversitesi, Ankara.

[66] Yoleri, S. ve Küçükyeşil, G. (2014). Okul öncesi dönem çocuklarının mizaç özellikleri ile dil becerileri arasındaki ilişkinin incelenmesi. Erzincan Üniversitesi Ĕ̈itim Fakültesi Dergisi, 16 (1).

[67] Yüksel, B. (2003). Eskişehir'de yaşayan 30-47 aylar arasındaki çocukların alıcı dil yapılarının incelenmesi. Yayımlanmamış yüksek lisans tezi, Hacettepe Üniversitesi, Ankara.

[68] Warner, R. (2008). Applied Statistics from Bivariate through Multivariate Techniques. Los Angeles: Sage Publications. 